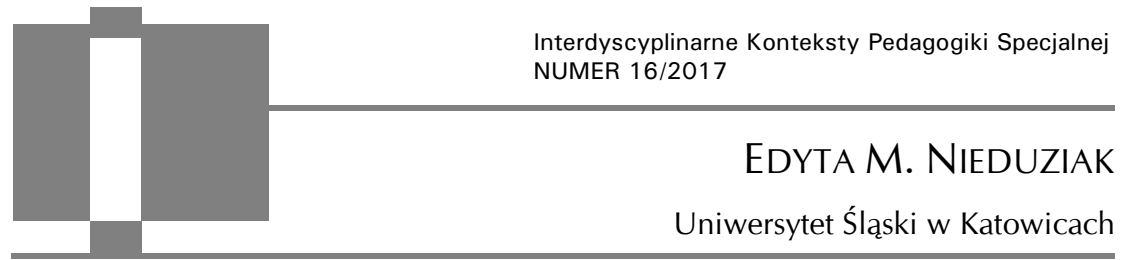

\title{
Twórczość Innego - nowa wartość w sztuce i w społeczeństwie?
}

\begin{abstract}
Edyta M. Nieduziak, Twórczość Innego - nowa wartość w sztuce i w spoteczenstwie? [The Art of the Other - a new value in the art and society?]. Interdyscyplinarne Konteksty Pedagogiki Specjalnej, nr 16, Poznań 2017. Pp. 163-183. Adam Mickiewicz University Press. ISSN 2300-391X
\end{abstract}

This article deals with the issues of creativity of people with disabilities and their social values. The starting point is the category of Another as saturated with pejorative meanings - in a social but positive context in the study of creativity. The combination of these contradictory approaches is reflected in the art brut, represented by artists with mental incompetence. Their creativity dictated by internal compulsion is presented as the work of marginalized people. The social context, as well as the type of disability that determines the way in which this art is treated: from the rejection of, for example, the early time of Nikifor's works, to the complete recognition of, for example, F. Kahlo's painting. The basic question, however, comes down to the question of the value of this art for man. Referring to the philosophy of E. Levinas, the author seeks to show that despite the assumption of the unknowability of another human being, the greatest value of the Other art is the ability to experience, to see though a fragment of the world of artists determined by the disability.

KEY WORDS: creativity of persons with disabilities, art brut, E. Levinas, Another 
Z punktu widzenia ściśle lekarskiego choroba psychiczna jest zjawiskiem szkodliwym, które czessto prowadzi do degradacji i zahamowania działalności twórczej, ale z perspektywy historii, poznania psychologicznego $i$ wartości kulturowych poszerzyła ona wiedze ludzka o takie obszary, których przyszło by może żałować, gdyby je skreślić z dziejów ludzkości.

Antoni Kępiński ${ }^{1}$

Już samo użycie w tytule artykułu pojęcia Inny zobowiązuje do odwołania się do rozumienia tej kategorii. Inny kojarzony jest w pierwszej kolejności z filozofią dialogu, a nade wszystko z myślą Emmanuela Lévinasa, dla którego inność była wartością absolutną, wyrazem ludzkiej podmiotowości i głębokiego dla niej szacunku. Ale jednocześnie nie tylko zgodą, co imperatywem niepoznawalności drugiego człowieka². „Filozof uważa, że poza całością mieści się pojedyncze Ja, będące jednak nie egzemplarzem Ja uniwersalnego, lecz samoistnym i nie dającym się z niczym porównać bytem”3. Do tych poglądów powrócę jednak $\mathrm{w}$ dalszej części artykułu. Tymczasem $\mathrm{w}$ potocznym odbiorze Inny rozumiany jest zgodnie ze słownikową definicją, jako „drugi, pozostały człowiek”, "nie ten, drugi, dalszy, pozostały, nie taki, różny, zmieniony, nowy", ",inszy" czy „owaki" 4 . Hanna Żuraw, analizując językowe konteksty tego słowa, zauważa, że można wyodrębnić jego cztery synonimiczne kategorie, wg których inny oznacza: dziwnego, odmiennego, niejednoznacznego oraz nienormalnego, anormalnego, zaburzonego ${ }^{5}$. Zatem Inny to również ten, kto nie posiada cech charakterystycznych dla większości, niemieszczący się w normie, ale wykraczający poza nią

1 A. Kępiński, Schizofrenia, PZWL, Warszawa 1981, s. 80.

2 E. Lévinas, Całość i nieskończoność. Esej o zewnętrzności, Wydawnictwo Naukowe PWN S.A., Warszawa 2014.

${ }^{3}$ H. Żółkowska, Ja, Ty, Inny - dialog?, „Studia Edukacyjne” 2013, nr 28, s. 23.

4 Stownik jezyka polskiego, hasło: inny https://sjp.pwn.pl/szukaj/inny.html [dostęp: 28.04.2017].

${ }^{5} \mathrm{H}$. Żuraw, Inność, obcość w perspektywie pozytywnej. Wielokontekstowość studiów nad innościa i obcościa [w:] Miejsce Innego we wspótczesnych naukach o wychowaniu. W poszukiwaniu pozytywów, red. I. Chrzanowska, B. Jachimczak, K. Pawelczak, Wydawnictwo Naukowe UAM, Poznań 2013, s. 15. 
albo jej nieosiągający. Taka interpretacja często wykorzystywana jest przez pedagogów specjalnych w dyskursie dotyczącym osób z niepełnosprawnością. Czasami, niestety, rozbieżność między normą a patologią legitymizowana wynikami badań nadaje pejoratywne znaczenie temu określeniu ${ }^{6}$. Jak pisze Joanna Głodkowska „w przypadku niepełnosprawności dokonuje się szczególnego rodzaju nałożenie dwóch rodzajów inności: inny, bo drugi człowiek, inny bo niepełnosprawny. Tego rodzaju nasilenie inności staje się źródłem postrzegania osoby z niepełnosprawnością jako nie tylko innej, ale wręcz obcej"7. W tym kontekście Innym staje się i ten, kto przeciwstawia się większości, kto do niej i do jej reguł nie pasuje bez względu na przyczyny. Tak rozumiana inność ma swój synonim - inny czyli specjalny8, obcy, a zatem nie-swój, nie-znany, być może wrogi. Przy tak przyjętych cechach dystynktywnych, można stwierdzić, że osoba sprawna też będzie Innym dla osób żyjących w środowisku zdominowanym przez osoby z dysfunkcjami. Inność i obcość zawsze wzbudzały społeczny dystans, wynikający z niemożliwości poznania, porozumienia za pomocą typowych środków. Inny, właśnie dlatego, że jest inny, wymaga odmiennego traktowania. W wielu kulturach Inność i odmienność są źródłem doświadczania działań opresyjnych i wykluczenia społecznego, czego chyba najradyalniejszym przykładem były i są zachowania dyskryminujące ze względu na kolor skóry czy przynależność religijną 9 .

Zgoła odmienne podejście do Innego można odnotować w badaniach i refleksji z zakresu psychologii twórczości czy krytyki sztuki. Inny jest synonimem niebanalności, niejednoznaczności,

${ }^{6}$ Por. A. Wojnarowska, Inny "uwięziony” w charakterystykach - o językowych uwikłaniach profesjonalistów $i$ ich konsekwencjach dla egzystowania człowieka $z$ niepetnosprawnością intelektualną, [w:] Miejsce innego..., s. 127-140.

${ }^{7}$ J. Głodkowska, Autorstwo życia a niepetnosprawność - ponawiane odczytywanie idei normalizacji, „Człowiek. Niepełnosprawność. Społeczeństwo” 2014, nr 1(23), s. 76.

${ }^{8}$ H. Żuraw, op. cit., s. 16-17.

9 Por. R. Kapuściński, Ten Inny, Wydawnictwo Znak, Kraków 2006, m.in. część Mój Inny, s. 41-51. 
nietypowości, fantazji, czegoś, co łamie konwenanse, prowokuje do myślenia, zaskakuje, szokuje; jest antonimem pospolitości, powszedniości, jednoznaczności ${ }^{10}$.

[...] nikt nigdy nie napisał biografii jakiejś twórczej osoby dlatego, że była to osoba najzupełniej normalna. [...] Ludzie twórczy; którzy są dziwakami i odmieńcami lub cierpią na jakąś chorobę psychiczną, stanowią o wiele lepszy materiał na fascynującą opowieść niż ludzie twórczy, którzy są nudni, ciężko pracują i mają udane życie małżeńskie,

pisał James Kaufman ${ }^{11}$. Odmienność fizyczna była częstym tematem twórczości wizualnej, by wspomnieć chociażby klasyczny przykład „Ślepców”, „Kalek” Pietera Bruegla starszego, „Niewidomego Wita Stwosza z wnuczką" Jana Matejki, jak również licznych ilustracji biblijnych przypowieści o cudownych uzdrowieniach osób chorych i niepełnosprawnych. W literaturze podajmy przykłady „Poczwarki” Doroty Terakowskiej12 albo „Oskara i pani Róży” Eica-Emmanuela Schmitta13. Krzysztof J. Szmidt wskazuje jednak na twórczość jako na kategorię pozytywną, której wartości społecznej nie należy wiązać z wykluczeniem czy dziwactwem. „Twórczość wiąże się z działaniami człowieka, który próbuje przekraczać granice tego, co zastane i kreować, dzięki swoim zdolnościom ogólnym lub specjalnym, wartościową nowość"14. Inność, jeśli rozumieć ją jako przejawiającą takie cechy jako nowość i oryginalność15, staje się odzwierciedleniem twórczości. Pomimo licznych dyskusji na temat sposobów jej

10 Por. J. Górniewicz, Kategorie pedagogiczne. Tolerancja. Twórczość. Wyobraźnia, Wydawnictwo UWM, Olsztyn 2001, s. 77-80.

11 J. Kaufman, Kreatywność, Wydawnictwo APS, Warszawa 2011, s. 105.

12 D. Terakowska, Poczwarka, Wydawnictwo Literackie, Kraków 2002.

${ }^{13}$ E. E. Schmitt, Oskar i pani Róża, Wydawnictwo Znak, Kraków 2004.

${ }^{14}$ K. J. Szmidt, Pedagogika pozytywna: twórczość - zdolności - mądrość zespolone [w:] Zasoby twórcze człowieka. Wprowadzenie do pedagogiki pozytywnej, red. K.J. Szmidt. M. Modrzejewska-Świgulska, Wydawnictwo UŁ, Łódź 2013, s. 35.

${ }_{15} \mathrm{~W}$ świetle definicji M. Steina, twórczość to proces prowadzacy do nowego wytworu, który jest akceptowany jako użyteczny lub do przyjęcia dla pewnej grupy w pewnym okresie, E. Necka, Psychologia twórczości, GWP, Gdańsk 2005, s. 17. 
rozumienia, twórczość jest definiowana poprzez odwołanie się do takich cech jak niejednoznaczność i zaskoczenie czy, jak pisał Jerome Bruner, prowokującą „skuteczne zdziwienie”, przez które rozumiał mieszankę szoku i akceptacji albo zaskoczenia i zgody ${ }^{16}$. Słowem inność, nawet jeśli budzi kontrowersje, jest cechą, którą wartościuje się pozytywnie. Zatem Inny jest nie tylko drugim człowiekiem, odmiennym ze względu na brak swojego miejsca wśród tych, którzy reprezentują tzw. normę, obcy, bo wychodzący czy też nieposiadający cech umożliwiających mu bycie w większości, obcy, bo funkcjonujący, żyjący poza swoimi, i na końcu Inny - niepowtarzalny i oryginalny.

Czy te cechy Innego przekładają się na jego działania? Mam tu na myśli szczególny rodzaj działań - twórczość artystyczną. Liczne badania biografii uznanych twórców oraz ich osobowości potwierdzają tezy o związkach między cechami twórczości a cechami osobowości ze szczególnym naciskiem na niepowtarzalność, oryginalność czasem również bunt, ekstrawagancję czy bezkompromisowość, a więc cechy utrudniające funkcjonowanie społeczne ${ }^{17}$. Często podkreśla się $\mathrm{w}$ tych badaniach znaczenie czynników zewnętrznych, zwłaszcza społecznych dla rozwoju twórczości albo dla jej uznania ${ }^{18}$. Zatem inność jako cecha przypisana także efektowi aktywności twórczej pozostaje ze wszech miar pożądana. Inność jednak, jako cecha ludzka, często staje się źródłem problemów. Piszącym o twórczości osób niepełnosprawnych trudność sprawia ocena dzieł. „Trudność polega na podjęciu decyzji o odsunięciu od siebie niepełnosprawności jako determinanty patrzenia na człowieka i recenzji efektów jego działalności, funkcjonowa-

${ }^{16}$ J.S. Bruner za E. Nęcka, op. cit., s. 31.

17 Por. M. Arana, The Writing Life: Writers on How They Think and Work, Public Affairs, New York 2003; G. Greengross, G.F. Miller, The Big Five personality traits of professional comedians compared to amateur comedians, comedy writers, and college students, „Personality and Individual Differences” 2009, nr 47(2); K. Łukasiewicz, Cechy osobowości młodych twórców podejmujących próby literackie, „Teraźniejszość. Człowiek. Edukacja" 2016, nr 3(75).

18 S. Popek, Człowiek jako jednostka twórcza, Wydawnictwo UMCS, Lublin 2001. 
nia"19 - pisze Ditta Baczała. Jednocześnie owa Inność staje się argumentem dla wykluczenia jednostki nawet $\mathrm{z}$ własnej grupy. Przywołam w tym miejscu postać Papuszy, genialnej cygańskiej poetki, wyklętej i odrzuconej przez własną społeczność ${ }^{20}$. Choć bywa, że uznanie twórczości Innego sprawia, iż łagodniejszym okiem patrzy się na ową Inność. Gdyby nie zaangażowanie Andrzeja Banacha i ryzykowna decyzja Diny Vierny o zorganizowaniu wystawy prac Nikifora w Paryżu, być może do dziś opowiadano by $\mathrm{o}$ „lokalnej atrakcji”, a nie o światowej sławy talencie.

Obrazków nie kupował nikt. Próbowaliśmy powiedzieć coś Nikiforowi, zapytać go, przejrzeć akwarele. Było to niemożliwe. Dzieci i przechodnie tworzyli ochronę i bronili dostępu. W miarę naszych prób zapora się wzmacniała, gwar i krzyk były coraz dotkliwsze, zobaczyliśmy między nami a Nikiforem mur. Dzieci zaczęły go trącać, a nas zasłaniać, w obawie, że zepsujemy im zabawę. Mieszkańcy Krynicy też się bali, że zabierzemy im osobliwość. [...] Pomoc dla człowieka mogła nadejść tylko przez uznanie artysty. Tu napotkaliśmy równie mocny mur, chroniący mistrza. Mur był zbudowany przez malarzy i zawodowych krytyków. Odkrycie Nikifora, problematyczne i śmieszne, uznanie żebraka za malarza równorzędnego, a nawet świetnego godziło w podstawy hierarchii oficjalnej sztuki i nauki o sztuce ${ }^{21}$.

Dzisiaj jednak hasła sztuki naiwnej, prymitywnej, Art brut funkcjonują w powszechnym języku, a ich przejawy są uznawane przez krytykę. Aczkolwiek należy przypomnieć, że kierunki te narodziły

${ }^{19}$ D. Baczała, Twórczość niepetnosprawna intelektualnie, [w:] Stymulowanie potencjału twórczego osób z różnymi potrzebami edukacyjnymi, red. E. Lubińska-Kościółek, K. Plutecka, Oficyna Wydawnicza „Impuls”, Kraków 2011, s. 82.

${ }^{20}$ Por. J. Ficowski, Cyganie polscy, PIW, Warszawa 1953; idem, Cyganie na Polskich drogach, Wydawnictwo Literackie, Kraków 1986; idem, Demony cudzego strachu: wspominki cygańskie, Ludowa Spółdzielnia Wydawnicza, Warszawa 1986; idem, Cyganie w Polsce. Dzieje $i$ obyczaje, Wydawnictwo Interpress, Warszawa 1989; A. Kuźniak, Papusza, Wydawnictwo Czarne, Wołowiec 2013.

${ }^{21}$ A. Banach, Nikifor, Wydawnictwo Arkady, Warszawa 1983, s. 14, 17. Dodajmy, że pierwsza książka A. Banacha o Nikiforze była pięciokrotnie odrzucana przez komisje wydawnicze. 
się z "potrzeby odnalezienia autentyzmu prawdy wypowiedzi w otaczającym nas, wykreowanym, sztucznym świecie"22. Dzięki uznaniu Art brut docenia się sztukę samouków, nieprofesjonalistów, którzy kierują się przymusem tworzenia oraz buntowniczym nastawieniem wobec norm i wartości zwłaszcza zbiorowych i którzy tworzą, nie dbając o opinię innych, zwłaszcza krytyków sztuki. Szczególną wartością przywróconą do łask dzięki Art brut jest wolność tworzenia, tym bardziej jeśli jest ona dyktowana wewnętrzną potrzebą, przymusem niemal.

Z pewnością sztuka Innych jest bardzo zindywidualizowana, ale tym samym wyłamuje się z ram przeciętności, dzięki niezależności od krytyki nie jest ograniczana czynnikami ekonomicznymi. Owa wolność od zdań krytyki i odbiorców daje możliwość eksperymentowania środkami wyrazu, poszukiwania stosownej formy wypowiedzi. „Artyści ci są nadzwyczajnie zwyczajni w swym autentyzmie i szczerości wypowiedzi, naiwni, nieulegający pokusom wyrachowanych strategii, wierni wyłącznie wewnętrznemu imperatywowi"23. Ich prace wzbudzają brunerowskie "skuteczne zdziwienie", często bowiem nie odpowiadają przyzwyczajeniom odbiorców, prowokują dystans i jednocześnie przykuwają uwagę, wciągają i kuszą. Artyści Art brut nadają codzienności ponadczasową jakość estetyczną, "tworzą sztukę poza czasem, chociaż ich czas najwyraźniej nadszedł, a model twórczości, który wybrali, święci obecnie triumfy"24. Można nie być entuzjastą Art brut, Outsi$\operatorname{der}$ Art, Visionary Art, self-taught art, art horsles-normes, art singulier, sztuki naiwnej, prymitywnej, innej - jakąkolwiek przypiszemy jej nazwę, pozostaje to jednak obecnie tylko sprawą gustu. Minęły czasy eliminowania jej i nazywania zdegenerowaną 25 wraz z akceptacją

${ }^{22}$ G. Borowik, A. Mironiuk-Nikolska, Wstęp, [w:] Gorzki smak Art brut. Badania kolekcje - wystawy w Polsce na przełomie XX/XXI wieku, Państwowe Muzeum Etnograficzne, Warszawa 2016, s. 9.

${ }^{23}$ G. Borowik, Czas sztuki Art brut, [w:] Gorzki smak..., s. 18.

24 Ibidem, s. 14.

${ }^{25}$ W 1937 r. w Monachium zorganizowano Wystawę Sztuki Zdegenerowanej, jako krytykę kierunków sprzecznych z oficjalnymi ideałami sztuki i piękna Niemiec. 
dla kierunków, które inspirowała takich jak ekpresjonizm, dadaizm, surrealizm, kubizm, fowizm. Jednakże twórczość artystyczna Innego, jak ją rozumem na potrzeby artykułu, nie ogranicza się jedynie do sztuk wizualnych ani do grupy osób dotkniętych doświadczeniem choroby psychicznej, jak to było u początków Art brut.

Trzeba przyznać, że różne formy wyrazu artystycznego będące dziełem Innych interesowały i interesują psychologów oraz psychiatrów. „Psychologowie i psychiatrzy próbowali badać normalność Nikifora. Stwierdzili, że jest nienormalny, że ma inteligencję niższą, po prostu żadną. Nie reaguje na przeciętne podniety. Powtarzało się słowo debil"26. A jednak ten "debil" okazał się utalentowanym malarzem, o którym dziś moglibyśmy powiedzieć, że jest świetnym przykładem zespołu sawanta. Ta niespójność cech społecznych i intelektualnych $\mathrm{z}$ twórczymi legła u podstaw badań z zakresu psychopatologii ekspresji - dyscypliny naukowej datującej swe początki w drugiej połowie XIX w. Jednakże, jak pisze jedna z jej prekursorek w Polsce, Magdalena Tyszkiewicz:

od chwili, gdy psychopatologia ekspresji zaczęła się wyodrębniać jako świadoma swego przedmiotu dyscyplina wiedzy, szczególne zainteresowanie badaczy budziły przede wszystkim formalne osobliwości wytworów plastycznych pacjentów chorych psychicznie. [...] Zaczęto też stawiać dwa różne pytania natury poznawczej. Jedno dotyczyło specyfiki świata, w którym żyje pacjent. Drugie dociekało osobliwości takiego a nie innego obrazowania tego, co pacjent zamierzał przedstawić27.

Dziś można powiedzieć, że ów drugi nurt problematyki badawczej ma swoje liczne publikacje będące efektem pracy psychiatrów, psychologów i krytyków sztuki, pedagogów, zwłaszcza specjalnych i kulturoznawców. Wiele wiemy np. na temat malarstwa osób chorych na schizofrenię28, coraz liczniejsze są próby opisania cech

${ }^{26}$ A. Banach, op. cit., s. 158.

${ }_{27}$ M. Tyszkiewicz, Psychopatologia ekspresji, PWN, Warszawa 1987, s. 10-11.

${ }^{28}$ Klasyczną jest pozycja A. Kępińskiego, Schizofrenia, op. cit., w której odwołuje się autor do wcześniejszej pracy H. Rennerta Die Merkmale Schizophrener Bildnerei, Jena 1962. Por. też: N. Madejska, Malarstwo i schizofrenia, Wydawnictwo Literackie, 
twórczości wizualnej osób z innymi zaburzeniami psychicznymi29 w tym również poparte ilościowymi materiałami badawczymi ${ }^{30}$, $\mathrm{z}$ niepełnosprawnością intelektualną ${ }^{31}, \mathrm{z}$ niepełnosprawnościami sensorycznymi ${ }^{32}$, zagrożonych niedostosowaniem społecznym ${ }^{33}$,

Kraków 1975; cykl artykułów M. Tyszkiewicz: Tematyka wypowiedzi plastycznych a postać defektu schizofrenicznego, "Psychiatria Polska” 1973, nr 3; Tematyka i forma malarstwa i rysunku chorych na schizofrenię, „Psychiatria Polska” 1980, nr 6; A. Grzywa, K. Kucharska-Pietura, Dynamika obrazu rodziny w pracach plastycznych chorych na schizofrenie paranoidalna, "Psychiatria Polska” 1998, nr 1(32); H. Welcz, Motywy sakralne w twórczości plastycznej chorych na schizofrenię, "Badania nad Schizofrenią" 2000 nr 2; H. Welcz, Schizofreniczna ekspresja plastyczna, "Current Problems of Psychiatry” 2010, nr 1(11); E. Nieduziak, P. Dec Twórczość plastyczna schizofreników studium przypadków, [w:] Twórczość jako forma dialogu ze światem, red. E. Nieduziak, WSH-P, Sandomierz 2010, s. 139-161.

${ }^{29}$ Np. A. Chmielińska, Twórczość „tych, którzy czują więcej”, [w:] Zasoby twórcze człowieka..., op. cit., s. 43-82.

${ }^{30}$ E. Głowacka, Artediagnoza: psychologiczna specyfika twórczości plastycznej dzieci neurotycznych, Wydawnictwo UJ, Kraków 2006.

${ }^{31} \mathrm{~Np}$. K. Krawiecka, Od znaku graficznego do rysunku. W poszukiwaniu twórczości osób z niepetnosprawnościa intelektualna, [w:] K. Krawicka, E. Śmiechowska-Petrovskij, M. Żelazkowska, Sztuka/twórczość dostępna. Osoby z niepetnosprawnościami i chorobq psychiczna w kręgu recepcji i ekspresji sztuki, Wydawnictwo Naukowe UKSW, Warszawa 2016; E. Nieduziak, Aktywność twórcza uczestników Warsztatu Terapii Zajęciowej przy Stowarzyszeniu "Integracja” w Sandomierzu, [w:] Człowiek z niepetnosprawnościa intelektualna T.2 Wybrane problemy społecznego funkcjonowania oraz rehabilitacji osób z niepetnosprawnością intelektualna, red. Z. Janiszewska-Nieścioruk, Oficyna Wydawnicza „Impuls”, Kraków 2004, s. 231-240; idem, Twórczość plastyczna osób z niepetnosprawnościa intelektualna, uczestników Warsztatu Terapii Zajęciowej - studium przypadku, [w:] Kreatywność osób z niepetnosprawnością intelektualna - czy umiemy myśleć inaczej? red. J. Głodkowska, A. Giryński, Wydawnictwo Naukowe Akapit, Kraków 2009, s. 191-197.

32 E. Nieduziak, Rzeźba osób głuchoniewidomych - zjawisko artystyczne, zjawisko terapeutyczne, „Człowiek - Niepełnosprawność - Społeczeństwo” 2011, nr 1 (13).

${ }^{33}$ E. Nieduziak, Projekcja jakości życia w ekspresji twórczej dzieci-uczestników zajęć $w$ świetlicy socjoterapeutycznej, [w:] Jakość życia młodzieży ze środowisk zagrożonych patologia społeczna, red. Z. Palak, M. Piątek, A. Róg, B. Zięba-Kołodziej Wydawnictwo Naukowe PWSZ, Tarnobrzeg 2011, s. 167-185; idem Wartości i uczucia w swobodnej ekspresji plastycznej $i$ w pracach arteterapeutycznych uczestników zajęć socjoterapeutycznych, [w:] W kierunku autentyczności. Twórcza ekspresja $i$ artyści z kręgu art brut, Wydział Sztuki Uniwersytet Pedagogiczny, Kraków 2011, s. 66-72. 
z chorobą przewlekłą ${ }^{34}$. Jednocześnie próby systematyzowania i charakteryzowania ogólnych i typowych cech twórczości osób marginalizowanych idą $\mathrm{w}$ parze $\mathrm{z}$ działaniami praktycznymi i rozwojem terapii przez sztukę (arteterapii). Prowadzenie badań w tej domenie wymaga badania nakładających się na siebie, a jednocześnie spójnych i wynikających z siebie płaszczyzn: kreacji - często związanej z jakimś fikcyjnym, nierealnym światem, i płaszczyzny realnego życia. W konsekwencji jednym z fundamentalnych pytań, na które badacz musi sobie odpowiedzieć, brzmi: co jest przedmiotem badań - terapia czy kreacja? Całość komplikuje możliwość zastosowania różnych dziedzin sztuki oraz ich wzajemnych kompilacji ${ }^{35}$. Warto jednak zatrzymać się przy tym terapeutycznym aspekcie twórczości Innego, choćby z tego powodu, że w wielu definicjach arteterapii podkreśla się twórczość jako niezbędny, konieczny i niezbywalny warunek tego procesu ${ }^{36}$. Zatem nie każdy kontakt ze środkami ekspresji artystycznej na miano terapii prze sztukę zasługuje. Ponadto trzeba pamiętać, że nie każda twórczość, nawet jeśli ma terapeutyczny potencjał, terapią jest i przez autora prac będzie tak rozumiany. Tym, co wydaje się najtrudniejsze w badaniu arteterapii, to oddzielenie świata fikcji od rzeczywistości. Owa przestrzeń między światami mieści w sobie ogromne zasoby terapeutyczne wykorzystywane przez artepsychoterapeutów, jak również w działaniach autoterapeutycznych często nieuświadamianych sobie przez twórców. Należy w tym miejscu dodać, że w swoim zapleczu teoretycznym terapia przez sztukę odwołuje się do psychologii humani-

${ }^{34}$ A. Stawecka, Rozwojowe walory twórczości plastycznej dzieci przewlekle chorych w okresie późnego dzieciństwa, [w:] Barwy twórczości, red. M. Kuśpit, UMCS, Lubin 2013.

$35 \mathrm{O}$ problematyczności art-based study i odwoływaniu się w badaniach do klasycznych podziałów na dziedziny sztuki, które wydaja się archaiczne w kontekście współczesnych przemian w sztuce mówiła prof. E. Rewers podczas VI Transdyscyplinarnego Sympozjum Badań Jakościowych we Wrocławiu w wystąpieniu Rywalizacja założeń ontologicznych w badaniach nad kultura.

36 Por. A. Chmielnicka-Plaskota, B. Łoza, W. Szulc, Definicje arteterapii, [w:] Arteterapia cz. 1, red. A. Chmielnicka-Plaskota, B. Łoza, Wydawnictwo Difin, Warszawa 2014. 
stycznej, psychoanalizy, koncepcji psychodynamicznych czy psychologii Gestalt ${ }^{37}$.

Uprawianie sztuki wiąże się $\mathrm{z}$ konstruowaniem odrębnego świata, w którym kreujący go czuje się pewnie. Jest to świat znany, oswojony, dający poczucie bezpieczeństwa m.in. dlatego, że to właśnie autor-kreator powołuje go do życia. Tworzy tak, jak chce i co chce. $\mathrm{W}$ tym świecie, uwidacznianym $\mathrm{w}$ postaci obrazów, utworów literackich, kreacji performatywnych czy muzycznych, można odnaleźć przejawy Inności, uwarunkowane stanem funkcjonowania psychofizycznego autora. Umożliwia to analiza formalna dziel, w której bierze się pod uwagę zastosowane kolory, efekty światłocienia, proporcje, perspektywę, fakturę, materię itp., słowem środki wyrazu artystycznego. Ale jest jeszcze obszar kreacji Innego bardzo mało zbadany - obszar świata wewnętrznego. I nie chodzi tu o jego przejawy w twórczości, lecz o odwrotny kierunek analizy. Poprzez kontakt z twórczością Innego można doświadczyć spotkania z jego światem osobistym. Jest to ów pierwszy nurt badań związany z psychopatologią ekspresji, a zarazem podróż oraz wysiłek zgoła metafizyczny - by powrócić do przywołanego na początku E. Lévinasa. „« «Tu nie ma prawdziwego życia». Ale jesteśmy w świecie. [...] Metafizyka zwraca się ku «gdzie indziej», ku «inaczej», ku «innemu» $[\ldots]$, jest ruchem wychodzącym od znanego nam świata nawet jeśli na jego skraju albo $\mathrm{w}$ nim skrywają się ziemie jeszcze nieznane - od «u siebie», które zamieszkujemy, w stronę obcego poza-sobą, w stronę jakiegoś «tam»"38. A zatem obcując $z$ twórczością Innego, oglądając obrazy np. wspomnianego Nikifora albo spektakle Lubelskiej Teatroterapiii3 ${ }^{39}$, podejmując lekturę Kokorynótw ${ }^{40}$

37 Arteterapia. Podręcznik, red. C.A. Malchiodi, Wydawnictwo Harmonia Universalis, Gdańsk 2012, rozdz. Arteterapia - podejście kliniczne, s. 79-176.

38 E. Lévinas, op. cit., s. 18.

39 http:/ / www.teatroterapia.lublin.pl/ [dostęp: 28.04.2017].

${ }^{40}$ Kokoryny, czyli opowieści dziwnej treści, Wydawnictwo Koziara Tararara, Lublin 2005. Książka jest zbiorem krótkich utworów literackich napisanych przez uczniów z mózgowym porażeniem mózgowym. Autorzy opowiadań: A. Dominicz, M. Kot, Ż. Tytko, A. Karcz, G. Jankowski, K. Nogieć, A. Jaskowski, G. Hull, 
albo Obłędu41, czy mam dostęp do świata wewnętrznego autorów tych prac? Przede wszystkim należy przyjąć, że mamy do czynienia $\mathrm{z}$ dziełami autentycznymi. Jest to warunek sine qua non. Jednocześnie, że mimo licznych analiz formalnych, nie istnieje żaden uniwersalny przewodnik do interpretacji dzieł Innego.

Identyczność aparatu wzrokowego nie zapewnia identyczności w postrzeganiu świata. Siłą, która stymuluje proces kreacji, są wyobraźnia i intuicja. W zależności od stanu emocjonalnego, otoczenia oraz rozmaitych bodźców towarzyszących, każdy człowiek przeżywa rzeczywistość inaczej, a co za tym idzie, ma niepowtarzalną, charakterystyczną dla siebie zdolność tworzenia ${ }^{42}$.

Zatem trzeba mieć świadomość, że nie istnieje żaden uniwersalny klucz do zrozumienia znaczeń zawartych w dziełach. Mało tego, twórcom zazwyczaj nie zależy na odczytywaniu ich przez innych, sami także często nie są ich świadomi. Rzecz całą komplikuje sam charakter środków wyrazowych: od literackich, przez wizualne po ich konglomerat $\mathrm{w}$ działaniach performatywnych (teatralnych i parateatralnych). Jak je czytać? Nie chodzi bowiem o interpretację dzieł, ich percepcję, lecz o przyjęcie perspektywy kogoś, kto pod powierzchnią barw, kształtów, słów, gestów itp. mówi o sobie.

Ryszard Kapuściński pisał, że „każde spotkanie z Innym jest zagadką, jest niewiadomą, jest [...] tajemnicą"43. Można również metaforycznie nazwać spotkanie „oswajaniem się z Innym”44. Jednakowoż spotkanie $\mathrm{z}$ twórczością Innego nie jest spotkaniem bezpośrednim, jest de facto spotkaniem z jego śladami i tworzonymi przez niego znakami. Twórczość artystyczną można przecież traktować jako formę komunikacji, zakładając, że jest „pełnym znaczeń komunikatem, informacją o człowieku, o sposobach postrzegania

G. Giermek, S. Wróbel. Na jej podstawie powstał spektakl Muzyka ze słowami, reż.

P. Cieplak, z J. Peszkiem i M. Peszek do muzyki zespołu Voo Voo.

41 J. Krzysztoń, Obtęd, PIW, Warszawa1980.

42 G. Borowik, op. cit., s. 14, 16.

${ }^{43}$ R. Kapuściński, op. cit., s. 11.

${ }^{44}$ R. Włodarczyk, Oswajać się z Innym. Kapuściński - Lévinas, „Odra” 2009, nr 3. 
i rozumienia przez niego świata" 45 . Grażyna Borowik używa określenia „świadectwo” na opisanie sztuki „artystów zwyczajnych, artystów szarego życia", których los i specyficzny talent umieścili na marginesie życia i sztuki ${ }^{46}$. Zatem stając $\mathrm{w}$ obliczu twórczości Innego, odbiorca może poczuć się jednak zagubiony i bezbronny, nie posiadając narzędzi do rozumienia znaczeń w niej zawartych. W przypadku twórczości literackiej pomocna bywa identyfikacja z fikcyjnym bohaterem albo otwartość, empatia, współczująca lektura dzienników, pamiętników czy twórczości epistemolograficznej. Żaden medyczny opis dysfunkcji nie odda jej doświadczania, tak jak jest to zawarte w książce Jerzego Krzysztonia czy Jean-Dominique'a Bauby:

Ból w piętach, głowa jak kowadło i rodzaj skafandra krepującego całe ciało. [...] Nie muszę długo się zastanawiać, by zorientować się, gdzie jestem, i przypomnieć sobie, że odpadłem od życia w piątek, 8 grudnia zeszłego roku ${ }^{47}$.

Zupełnie innym kodem posługują się twórcy wizualni. Skoro jednak wybrali taką formę ekspresji, oznacza to, że tym tropem należy podążać na spotkanie z Innym. Godząc się z faktem, że „nie wszystko [...] można odczytać, rozszyfrować, zrozumieć logicznie" $^{\prime \prime}$. Warto jednak dodać, że wielu twórców nie ogranicza się do jednej tylko formy ekspresji. O doświadczeniu choroby dowiemy się nie tylko z obrazów Fridy Kahlo, ale również z dzienników malarki; malarstwo Christy Browna uzupełnia twórczość pisarska i poetycka. Należy jeszcze za Joanną Głodkowską zauważyć, że Inność osoby „przenosi” się na jej bliskich, osoby związane z jej życiem ${ }^{49}$. Niewiele byśmy o Innych wiedzieli, gdyby nie lektura dzienników rodziny Ingmara Bergmana, esejów syna Susan Son-

\footnotetext{
45 G. Borowik, op. cit., s. 40.

46 Ibidem, s. 18-19.

47 J.D. Bauby, Skafander i motyl, Słowo obraz terytoria, Gdańsk 1997, s. 7.

${ }^{48}$ G. Borowik, op. cit., s. 20.

49 J. Głodkowska, op. cit., s. 76.
} 
tag50, blogów internetowych prowadzonych przez rodziców i opiekunów osób z niepełnosprawnościami. Słowo często jest koniecznym dopełnieniem obrazów - znajdziemy je w dziennikach Fridy Kahlo, Antonina Artauda, ale również w obrazach Marii Wnęk.

Artysta mówi o sztuce jako fachowiec i jako twórca. Mówi o sztuce jako o rzeczy, do której się zbliżył całym istnieniem. Mówi jak praktyk, który zna opór tworzywa i technikę przemiany myśli twórczej na dzieło konkretne. Mówi jako ten, który przeżywał procesy twórcze i może mówić o tym, co w całej pełni przeżył ${ }^{51}$.

Jego słowo może więc pomóc w odczytaniu wskaźników zawartych w formie wizualnej, przybliżyć rzeczywiste problemy, konflikty, lęki, marzenia czy wyobrażenia. Uchyla rąbka tajemnicy tworzenia i życia artysty.

Zjednoczeniem obrazu, słowa, fabuły bywa twórczość filmowa, którą w wybranych okolicznościach można potraktować jako formę zapisu doświadczenia ubranego w filmową fikcję. Oglądając np. „33 sceny z życia”52 Małgorzaty Szumowskiej i mając jednocześnie choćby namiastkę wiedzy o osobistych przeżyciach reżyserki zawartych w scenariuszu, jako widz zostaję postawiona także w pozycji świadka, nie tylko odbiorcy, interpretatora, widza. Do jeszcze bardziej skomplikowanej sieci śladów, znaków i znaczeń dochodzi w sztukach performatywnych, zwłaszcza w sytuacji nieukrywania przed odbiorcami Inności, która staje się widocznym i znaczącym znakiem. Świadomość Inności rzeczywistej, a nie kreowanej przekłada się na sposób rozumienia dzieła i rodzi pytania o to, jak ważna jest wartości tego znaku w kontekście całego dzieła. Oglądając

50 Por. E. Nieduziak, Literackie dzienniki umierania jako forma oswajania ze śmiercia, [w:] Człowiek w sytuacji granicznej. Filozoficzne, kulturowe i historyczne wymiary refleksji i jej implikacje pedagogiczne, red. S. Jaronowska, Wydawnictwo APS, Warszawa 2015, s. 154-169.

51 S. Szuman, Wstęp, [w:] W. Lam, Twórczość przejawem instynktu życia, KAW, Gdańsk 1977, s. 7.

5233 sceny z życia, reż. i scen. M. Szumowska, produkcja: Polska, Niemcy, premiera 10 sierpnia $2008 \mathrm{r}$. 
przedstawienie głuchoniewidomej aktorki zespołu Nalaga'at Theatre Bat Shevy Revensari widzowie poza przeżyciem estetycznym mogą stać się częścią doświadczenia, jej osobistej historii ${ }^{53}$. Podobnie oglądając Krzysztofa Globisza w roli „Wieloryba”54, słuchając wypowiadanych przez aktora słów np. tych Fernando Pessoi „Bywa, że odczuwam wszystko./Przez chwilę jestem bardziej różnorodny/niż przypadkowy tłum./Wszystkie epoki przez chwilę do mnie należą./Wszystkie dusze przez chwilę mają swoje miejsce/we mnie./Lecz są takie fale,/ takie nawałnice i szkwały,/które powodują,/że ocean się cały oddziela ode mnie./Wtedy zostaje się z niczym"55 - można rozumieć je jako monolog tytułowego morskiego ssaka - i na tym poziomie odbioru pozostać, ale również odnieść je do osobistej sfery życia aktora zmagającego się ze skutkami przebytego udaru.

W tym miejscu należy postawić pytanie o to, czy odbiorca (widz, czytelnik, oglądający) mają prawo do takiej formy odbioru? Przede wszystkim więc należy wyraźnie podkreślić, że w proponowanym sposobie kontaktu z twórczością Innego nie o zwykły odbiór ani interpretację dzieła chodzi, lecz o niezwykłe spotkanie z drugim człowiekiem. Zatem chodzi i o doświadczenie zgoła odmienne, o Levinasowskie „wydarzenie” możliwe jedynie w twórczości głęboko autentycznej. Dla przykładu, jak mówi Mateusz Pakuła, scenarzysta Wieloryba, „Dla niektórych ten spektakl jednak nie wykracza poza terapię. Uznają, że to nie jest sztuka, w związku $\mathrm{z}$ tym nie porusza ich to tak mocno. Lub porusza ich $\mathrm{w}$ ten sposób, że irytuje - nie są w stanie zaakceptować [...] rozmaitych przekro-

${ }^{53}$ Nalaga'at (tzn. dotknij) jest grupą teatralną, skupiającą osoby niewidome i niesłyszące. W nazwie zespół nawiązuje do podstawowego komunikowania się jakim jest dotyk. Grupa gościła w Polsce dwukrotnie, ostatnio podczas Festiwalu Brave we Wrocławiu w 2016 r. z przedstawieniem „Say «Orange»" reż. S. Sibony Więcej na: http://nalagaat.org.il/en/theater-2/ oraz http://nalagaat.org.il/en/the ater-2/say-orange/ [dostęp: 28.04.2017].

${ }^{54}$ Wieloryb the Globe, reż. E. Rysova, tekst i dramaturgia: M. Pakuła; premiera 9.12.2016. Por. J. Kopciński, Globisz, „Teatr” 2017, nr 2, s. 6-9.

55 Wieloryb the Globe, reż. E. Rysova, tekst i dramaturgia: M. Pakuła. 
czeń, bo one są poza estetyką i wyobrażeniem o spójności w teatrze" ${ }^{\prime 56}$. Proponowane spotkanie z twórczością Innego wykracza poza sferę estetycznych konwencji, poza interpretacje psychologiczne oraz traktowanie jej jako sposobu leczenia.

Ryszard Kapuściński pisał, że spotkanie z Innym opiera się na dwoistości: na tym, co jest wspólne i typowe, i na tym, co wynika $\mathrm{z}$ rasy i uwarunkowań kulturowych.

Problem jednak $\mathrm{w}$ tym [...] że ta istniejąca $\mathrm{w}$ każdym $\mathrm{z}$ nas relacja miedzy człowiekiem - jednostką, indywidualnością i osobowością, a człowiekiem - nosicielem kultury i rasy, nie jest $\mathrm{w}$ nim samym nieruchoma, sztywna, statyczna, dana raz na zawsze, ale przeciwnie - cechuje ją dynamika, ruchliwość, zmienność, różnice natężenia, w zależności od kontekstu zewnętrznego, wymogów chwili bieżącej, oczekiwaniom otoczenia, a nawet - naszego własnego nastroju i wieku ${ }^{57}$.

Stanowisko to można przenieść na relacje z twórczością Innego, której rozumienie nie powinno być jednoznaczne, tym bardziej rozumiejąc je jako spotkanie z Innym. Nie ma dwóch identycznych spotkań, są uzależnione od obu stron. Wyruszając jednak na spotkanie z twórczością Innego, należy przyjąć postawę tego, który „nic nie wie”, "nie zna się”, postawę pokory i otwartości. Dlatego jako przestrogę należy potraktować słowa Lévinasa o porzuceniu dyskursu pedagogicznego czy psychagogicznego, które określił jako

mówienie z pozycji kogoś, kto chce przechytrzyć bliźniego. [...] Nie staje ona [retoryka] naprzeciw Innego, lecz podchodzi do niego z ukosa, choć nie traktuje go jak rzecz, bo pozostaje mową i mimo wszystkich swych sztuczek zwraca się do Innego, zabiega o jego "tak". [...] Zrezygnować z psychagogii, demagogii, pedagogii, jakie zawiera retoryka to stawać naprzeciw innego człowieka w sytuacji prawdziwego dyskursu ${ }^{58}$.

\footnotetext{
${ }^{56}$ K. Kusinowska, Modlitwa wygnańca, „Tygodnik Powszechny” 2017, nr 28, s. 65.

57 R. Kapuściński, op. cit., s. 10.

58 E. Lévinas, op. cit., s. 68.
} 
Jednym z warunków powodzenia spotkania jest uznanie wolności Innego, jego niezależności w świecie, jaki tworzy. Jednocześnie konieczna jest zgoda na niepowtarzalność tego świata. Skoro jest wyrazem wolości, tzn. że powstał nie dla chęci pokazania się, lecz $\mathrm{z}$ potrzeby tworzenia. Zatem dzieło jako komunikat jest też wtórne wobec samego wewnętrznego przymusu kreacji.

Dlaczego jednak to spotkanie miałoby być ważne dla nieInnego? Dlatego, że poznając Innych, lepiej poznaje siebie, bo Inny jest jego zwierciadłem, bo „aby zrozumieć lepiej samych siebie, trzeba lepiej zrozumieć Innych, móc się z nimi porównać, zmierzyć, skonfrontować"59. Powtórzyć jednak należy, że jest to spotkanie przebiegające w osobliwych warunkach, w których często słowo traci nadrzędną moc na rzecz innych środków wyrazu. Słowo bywa dopełnieniem, wskazówką jak podążać za Innym. Taki układ podkreśla jeszcze bardziej Lévinasowską asymetryczność relacji z Innym, polegającą m.in. na tym, że „w Innym widzę nauczyciela, mistrza. Równość osób sama w sobie nic nie znaczy. [...] Polega na uznaniu wyższości Innego i jego mistrzostwa, jest kontaktem z innym człowiekiem ponad retoryką"60. Inny jest zawsze różny od Ja, jest niezastępowany i nieprzechodni co znaczy, że Ja nie może stać się Innym ${ }^{61}$. Jak pisze Barbara Skarga - spotkanie tworzy pewne ramy, które trzeba wypełnić własnym doświadczeniem i obserwacją, „inny i ja nie znajdują się w jednej płaszczyźnie; inny przemawia jakby z wysokości, nakazuje mi się wznieść ponad siebie"62. W konfrontacji z działalnością artystyczną Innego, znaczenia nabiera wyczulenie na inne, pozasłowne formy porozumiewania się

ktoś nadchodzi. Bez uprzedzenia. Zapach, smak, linia, gest, słowo, szczegół, fragment dają do ręki nitkę, po której wraca się do siebie, jednocześnie pomagając przekroczyć czas, to, kim w danej chwili jesteśmy

${ }^{59}$ R. Kapuściński, op. cit., s.14.

${ }^{60}$ E. Lévinas, op. cit., s. 70.

${ }^{61} \mathrm{R}$. Włodarczyk, Lévinas. W strone pedagogiki azylu, Wydawnictwo UW, Warszawa 2009, s. 176.

62 B. Skarga, Wstęp, [w:] E. Lévinas, op. cit., s. XX. 
[...] Inny we mnie rezonuje z Innym poza mną. Obaj domagają się pokonania oporu bezpiecznego zamieszkiwania w tu i teraz, ponawianego wysiłku mojego z nimi oswajania się ${ }^{63}$.

Dlatego tak ważne są inne poza słowem drogi wiodące do spotkania. Wielu twórców Innych nie posługuje się słowem, które samo w sobie staje się ułomne i niewystarczające wobec tego, co można wyrazić obrazem, dźwiękiem, gestem oraz ich zestawieniami. I to jest również dialog.

\section{Bibliografia}

Arana M., The Writing Life: Writers on How They Think and Work, Public Affairs, New York 2003.

Arteterapia. Podręcznik, red. C.A. Malchiodi, Wydawnictwo Harmonia Universalis, Gdańsk 2012.

Baczała, Twórczość niepetnosprawna intelektualnie, [w:] Stymulowanie potencjału twórczego osób z różnymi potrzebami edukacyjnymi, red. E. Lubińska-Kościółek, K. Plutecka, Oficyna Wydawnicza „Impuls”, Kraków 2011.

Banach A., Nikifor, Wydawnictwo Arkady, Warszawa 1983.

Bauby J.D., Skafander i motyl, Słowo obraz terytoria, Gdańsk 1997.

Borowik G., Czas sztuki Art brut, [w:] Gorzki smak Art brut. Badania - kolekcje - wystawy w Polsce na przełomie XX/XXI wieku, Państwowe Muzeum Etnograficzne, Warszawa 2016.

Borowik G., Mironiuk-Nikolska A., Wstęp, [w:] Gorzki smak Art brut. Badania - kolekcje - wystawy w Polsce na przełomie XX/XXI wieku, Państwowe Muzeum Etnograficzne, Warszawa 2016.

Chmielińska A., Twórczość "tych, którzy czuja więcej”, [w:] Zasoby twórcze człowieka. Wprowadzenie do pedagogiki pozytywnej, red. K.J. Szmidt. M. ModrzejewskaŚwigulska, Wydawnictwo UŁ, Łódź 2013.

Chmielnicka-Plaskota A., Łoza B., Szulc W., Definicje arteterapii, [w:] Arteterapia cz. 1, red. A. Chmielnicka-Plaskota, B. Łoza, Wydawnictwo Difin, Warszawa 2014.

E. Necka E., Psychologia twórczości, GWP, Gdańsk 2005.

Ficowski J., Cyganie na Polskich drogach, Wydawnictwo Literackie, Kraków 1986

Ficowski J., Cyganie polscy, PIW, Warszawa 1953.

63 R. Włodarczyk, op. cit., s. 32. 
Ficowski J., Cyganie w Polsce. Dzieje i obyczaje, Wydawnictwo Interpress, Warszawa 1989.

Ficowski J., Demony cudzego strachu: wspominki cygańskie, Ludowa Spółdzielnia Wydawnicza, Warszawa 1986.

Głowacka E., Artediagnoza: psychologiczna specyfika twórczości plastycznej dzieci neurotycznych, Wydawnictwo UJ, Kraków 2006.

Górniewicz J., Kategorie pedagogiczne. Tolerancja. Twórczość. Wyobraźnia, Wydawnictwo UWM, Olsztyn 2001.

Kapuściński R., Ten Inny, Wydawnictwo Znak, Kraków 2006.

Kaufman J., Kreatywność, Wydawnictwo APS, Warszawa 2011.

Kępiński A., Schizofrenia, PZWL, Warszawa 1981.

Kokoryny, czyli opowieści dziwnej treści, Wydawnictwo Koziara Tararara, Lublin 2005.

Krawiecka K., Od znaku graficznego do rysunku. W poszukiwaniu twórczości osób z niepetnosprawnością intelektualna, [w:] K. Krawicka, E. Śmiechowska-Petrovskij, M. Żelazkowska, Sztuka/twórczość dostępna. Osoby z niepetnosprawnościami i choroba psychiczna w kręu recepcji i ekspresji sztuki, Wydawnictwo Naukowe UKSW, Warszawa 2016.

Krzysztoń J., Obłęd, PIW, Warszawa1980.

Kuźniak A., Papusza, Wydawnictwo Czarne, Wołowiec 2013.

Lévinas E., Całość i nieskończoność. Esej o zewnętrzności, Wydawnictwo Naukowe PWN S.A., Warszawa 2014.

Madejska N., Malarstwo i schizofrenia, Wydawnictwo Literackie, Kraków 1975

Nieduziak E., Aktywność twórcza uczestników Warsztatu Terapii Zajęciowej przy Stowarzyszeniu "Integracja” w Sandomierzu, [w:] Człowiek z niepetnosprawnościa intelektualna T.2 Wybrane problemy społecznego funkcjonowania oraz rehabilitacji osób $z$ niepetnosprawnościa intelektualna, red. Z. Janiszewska-Nieścioruk, Oficyna Wydawnicza „Impuls”, Kraków 2004.

Nieduziak E., Dec P., Twórczość plastyczna schizofreników - studium przypadków, [w:] Twórczość jako forma dialogu ze światem, red. E. Nieduziak, WSH-P, Sandomierz 2010.

Nieduziak E., Literackie dzienniki umierania jako forma oswajania ze śmiercia, [w:] Człowiek w sytuacji granicznej. Filozoficzne, kulturowe i historyczne wymiary refleksji $i$ jej implikacje pedagogiczne, red. S. Jaronowska, Wydawnictwo APS, Warszawa 2015.

Nieduziak E., Projekcja jakości życia w ekspresji twórczej dzieci - uczestników zajęć w świetlicy socjoterapeutycznej, [w:] Jakość życia młodzieży ze środowisk zagrożonych patologia społeczną, red. Z. Palak, M. Piątek, A. Róg, B. Zięba-Kołodziej, Wydawnictwo Naukowe PWSZ, Tarnobrzeg 2011.

Nieduziak E., Twórczość plastyczna osób z niepetnosprawnościa intelektualna, uczestników Warsztatu Terapii Zajęciowej - studium przypadku, [w:] Kreatywność osób z niepetnosprawnościq intelektualna - czy umiemy myśleć inaczej?, red. J. Głodkowska, A. Giryński, Wydawnictwo Naukowe Akapit, Kraków 2009. 
Nieduziak E., Wartości i uczucia w swobodnej ekspresji plastycznej i w pracach arteterapeutycznych uczestników zajęć socjoterapeutycznych, [w:] W kierunku autentyczności. Twórcza ekspresja i artyści z kręgu art brut, Wydział Sztuki Uniwersytet Pedagogiczny, Kraków 2011.

Popek S., Człowiek jako jednostka twórcza, Wydawnictwo UMCS, Lublin 2001.

Schmitt E.E., Oskar i pani Róża, Wydawnictwo Znak, Kraków 2004.

Skarga B., Wstęp, [w:] E. Lévinas, Catość i nieskończoność. Esej o zewnętrzności, Wydawnictwo Naukowe PWN S.A., Warszawa 2014.

Stawecka A., Rozwojowe walory twórczości plastycznej dzieci przewlekle chorych w okresie późnego dzieciństwa, [w:] Barwy twórczości, red. M. Kuśpit, UMCS, Lublin 2013.

Szmidt K.J., Pedagogika pozytywna: twórczość - zdolności - madrość zespolone, [w:] Zasoby twórcze człowieka. Wprowadzenie do pedagogiki pozytywnej, red. K.J. Szmidt. M. Modrzejewska-Świgulska, Wydawnictwo UŁ, Łódź 2013.

Szuman S., Wstęp, [w:] W. Lam, Twórczość przejawem instynktu życia, KAW, Gdańsk 1977.

Terakowska D., Poczwarka, Wydawnictwo Literackie, Kraków 2002.

Tyszkiewicz M., Psychopatologia ekspresji, PWN, Warszawa 1987.

Włodarczyk R., Lévinas. W strone pedagogiki azylu, Wydawnictwo UW, Warszawa 2009.

Wojnarowska A., Inny "uwięziony” w charakterystykach - o językowych uwiktaniach profesjonalistów $i$ ich konsekwencjach dla egzystowania człowieka $z$ niepetnosprawnościa intelektualna, [w:] Miejsce innego we wspótczesnych naukach o wychowaniu. W poszukiwaniu pozytywów, red. I. Chrzanowska, B. Jachimczak, K. Pawelczak, Wydawnictwo Naukowe UAM, Poznań 2013.

Żuraw H., Inność, obcość w perspektywie pozytywnej. Wielokontekstowość studiów nad innością i obcościa, [w:] Miejsce Innego we wspótczesnych naukach o wychowaniu. W poszukiwaniu pozytywów, red. I. Chrzanowska, B. Jachimczak, K. Pawelczak, Wydawnictwo Naukowe UAM, Poznań 2013.

\section{Wydawnictwa ciągłe}

Głodkowska J., Autorstwo życia a niepetnosprawność - ponawiane odczytywanie idei normalizacji, „Człowiek. Niepełnosprawność. Społeczeństwo” 2014, nr 1(23).

Greengross G., Miller G.F., The Big Five personality traits of professional comedians compared to amateur comedians, comedy writers, and college students, „Personality and Individual Differences" 2009, nr 47(2).

Grzywa A., Kucharska-Pietura K., Dynamika obrazu rodziny w pracach plastycznych chorych na schizofrenię paranoidalna, „Psychiatria Polska” 1998, nr 1(32).

Kopciński J., Globisz, „Teatr” 2017, nr 2.

Kusinowska K., Modlitwa wygnańca, „Tygodnik Powszechny” 2017, nr 28.

Łukasiewicz K., Cechy osobowości młodych twórców podejmujących próby literackie, „Teraźniejszość. Człowiek. Edukacja” 2016, nr 3(75). 
Nieduziak E., Rzeźba osób głuchoniewidomych - zjawisko artystyczne, zjawisko terapeutyczne, „Człowiek - Niepełnosprawność - Społeczeństwo” 2011, nr 1(13).

Tyszkiewicz M., Tematyka i forma malarstwa i rysunku chorych na schizofrenię, „Psychiatria Polska" 1980, nr 6.

Tyszkiewicz M., Tematyka wypowiedzi plastycznych a postać defektu schizofrenicznego, „Psychiatria Polska” 1973, nr 3.

Welcz H., Motywy sakralne w twórczości plastycznej chorych na schizofrenię, "Badania nad Schizofrenią" 2000, nr 2.

Welcz H., Schizofreniczna ekspresja plastyczna, „Current Problems of Psychiatry” 2010, nr 1(11).

Włodarczyk R., Oswajać się z Innym. Kapuściński - Lévinas, „Odra” 2009, nr 3.

Żółkowska H., Ja, Ty, Inny - dialog?, „Studia Edukacyjne” 2013, nr 28.

Netografia. Data dostępu: 28.04.2017

Słownik języka polskiego, hasło: inny https://sjp.pwn.pl/szukaj/inny.html

http://www.teatroterapia.lublin.pl/

http://nalagaat.org.il/en/theater-2/

http://nalagaat.org.il/en/theater-2/say-orange/

Przedstawienia teatralne

Muzyka ze słowami, reż. P. Cieplak, premiera 23.02.2002 Teatr Studio im. St. I. Witkiewicza Warszawa.

Say Orange, reż. S. Sibony, Nalaga' at Theatre.

Wieloryb the Globe, reż E. Rysova, tekst i dramaturgia: M. Pakuła; premiera 7.12.2016, Teatr Łaźnia Nowa Kraków.

Filmografia

33 sceny z życia, reż. i scen. M. Szumowska, produkcja: Polska, Niemcy, premiera 10 sierpnia $2008 \mathrm{r}$. 